\title{
Circulation Policies in Major Academic Libraries
}

\author{
Duane E Wilson \\ duane_wilson@byu.edu \\ Cynthia Frazier \\ Brigham Young University, Provo Utah, cynthia_frazier@byu.edu \\ Diana Harter \\ Brigham Young University, Provo, Utah, diana_harter@byu.edu
}

Follow this and additional works at: https://scholarsarchive.byu.edu/facpub

Part of the Library and Information Science Commons

\section{Original Publication Citation}

Duane Wilson, Cynthia Frazier, Diana Harter. Circulation Policies in Major Academic Libraries.

The Journal of Academic Librarianship. Volume 41, Issue 6, Pages 798-803.

\section{BYU ScholarsArchive Citation}

Wilson, Duane E; Frazier, Cynthia; and Harter, Diana, "Circulation Policies in Major Academic Libraries" (2015). Faculty Publications. 1600.

https://scholarsarchive.byu.edu/facpub/1600

This Peer-Reviewed Article is brought to you for free and open access by BYU ScholarsArchive. It has been accepted for inclusion in Faculty Publications by an authorized administrator of BYU ScholarsArchive. For more information, please contact ellen_amatangelo@byu.edu. 
Title: Circulation Policies in Major Academic Libraries

Abstract

As part of an assessment of its patron circulation policies, Brigham Young University's Harold B. Lee

Library Circulation Committee studied the circulation policies of ARL members and like-sized academic institution's libraries. Access Services Department Heads or their equivalent at 165 academic libraries were surveyed. This paper reports on policies relating to circulation, renewals, fines, and recalls for these libraries. The majority of circulation policies are traditional (typical circulation periods, low numbers of renewals and traditional fines), though non-traditional policies (longer circulation periods, more renewals, and elimination of fines) provide better service and satisfaction for patrons. Libraries should examine their policies to determine if non-traditional policies would work at their institution.

\section{Keywords:}

Circulation, Academic Libraries, Fines, Recalls, Circulation Periods, Circulation Policies

\section{Introduction}

Despite its continuous decline over many years, circulation is still a major function of almost all libraries. There continue to be many important issues to be resolved regarding circulation periods, fines, and recalls, especially given the decrease in circulation. In spite of these issues and the importance of circulation, little study has been done to examine circulation policies at major academic libraries. As a result of this assessment gap, the Circulation Committee at Brigham Young University set out to discover what policies were typical at other major academic libraries in order to inform its own circulation policies. 


\section{Literature Review}

Though there are no articles providing data about circulation periods in major libraries, there have been several articles discussing the policies for loan periods, renewals, fines, and recalls. These are discussed below.

\section{Loan Periods}

Brophy and Moorehouse (1984) reported that variable loan circulation periods, determined by heavy or light demand for certain books, were implemented by Teesside Polytechnic Library. Hartse and Lee (1992) discussed how data from peer ALA institutions encouraged changes to Arizona State University Library's circulation policy including loan periods for graduates, fines, and unseen renewals. Changes in loan periods and fines, implemented at Babst Library at NYU, were evaluated and reported in an article by Rupp, Sweetman and Perry (2010). They lengthened loan periods and eliminated fines for the general collection, causing fewer billed books and increased patron satisfaction. Wilson (2014) described the process of assessing circulation policies, which indicated the need to increase undergraduate loan periods at the Brigham Young University Harold B. Lee Library.

\section{Renewals}

Sifton (2009), reported that various libraries have abolished overdue fines in favor of renewals. When renewals run out and the item is not returned, the person with the item is blocked from checking out additional library materials. Returning the book removes the block and restores patron privilege. Zweibel and Lane (2012) described the quantitative results of policy changes made in circulation practices at Columbia University libraries in 2003-4 and 2009-10. They reported an increase in undergraduate circulation periods and subsequent decrease of renewals in that group. 
Fines

Discussions of how to improve fine policy or even eliminate fines have been regularly mentioned in library literature. An evaluation of circulation policy at the University of Cincinnati Medical Center Libraries was made to decrease staff processing time for overdue materials as well as better meet user need. For them, instituting a first overdue notice containing replacement costs of the item and then a final notice greatly increased timely returns of library materials (Fried \& Hurlebaus 1981).

Burgin \& Hansel (1984) discussed solutions to improve patron relations with the library through fine policy changes. They reported that libraries with no fines had more items circulated, more items returned, and increased patron satisfaction with the library generally. Shontz (1999) questioned the effectiveness of trying to modify user behavior with fines. He reported that one of the main points determining when patrons return library items is 'when the user is finished with the item' and that if a user still needed an item they would keep it whether there was a fine levied or not. Mosley (2004) discussed the problems involved and costs incurred by staff in processing and collecting fines compared to the income fines generated. Their decision was to eliminate overdue fines for general stacks books at Texas A\&M libraries. She also notes that billing patrons for long overdue or 'LOST' books in many cases encouraged their return. Sung and Tolppanen (2013) found that fines make a difference in whether books are returned on time, but stressed that assessing fines harms the library image and impedes patron access. A year-long study about circulation issues reported by Reed, Blackburn and Sifton (2014) resulted in their recommendation that libraries carefully examine long-held library practices of fines and loan periods and make changes that encourage good will and library use.

\section{Recalls}

Recall policy has rarely been discussed in the literature. Goehlert (1979) reported that the Indiana University Library began fining faculty for recalled items when a study of their patrons showed that this group was far less responsive to recall notices than other borrowers. Dethloff (2012) explained how the 
University of Houston replaced recalls with interlibrary loan and how this 'Quick Loan' process has done away with 'recall wars' and has increased customer satisfaction.

After examining the literature, the circulation committee found that there was a lack of comparative information about circulation policies in academic libraries. Though the various articles were helpful, they were primarily reports on localized studies and policies. Seeking to address this gap, the circulation committee pursued a study on circulation policies at major academic libraries in the United States.

\section{Methods}

To determine circulation policies in major academic libraries, the Harold B. Lee Library Circulation Committee chose to survey libraries from academic institutions with enrollment similar to BYU. BYU is a member of the Association of Research Libraries (ARL), which creates a natural peer group for comparison. Because BYU is an academic library in the United States, the committee eliminated the 16 Canadian and 9 non-university libraries from the list of 125 ARL libraries, selecting the 100 academic libraries in the United States. The committee also used the National Center for Educational Statistics (NCES) "Compare Academic Libraries" tool to find other academic institutions with large enrollments. Using the tool, the committee selected libraries that offer at least a bachelor's degree with enrollments of 16,809-57,271. These numbers were chosen because of the technical limitations in selecting enrollment numbers with the compare libraries tool. The intent was to find large institutions with student populations that were within about 15,000 students of BYU's enrollment. This method provided 65 additional institutions that were not on the ARL list, for a total of 165 unique institutions. The committee created a survey with questions that asked about specific circulation policies at the libraries surveyed. The full text of this survey can be found in Wilson 2014. This survey was emailed to identifiable heads of circulation or access services in the libraries of selected 
institutions. Seventy-six institutions completed the survey for a response rate of $46 \%$. No demographic data was collected as part of this survey.

\section{Results}

\section{Circulation}

Respondents were first asked what the standard circulation period was for a variety of patron types. In order to include all of the different ways that libraries measured circulation periods (day, week, month, term, semester, etc.) respondents were presented with the patron types of undergraduate, graduate, staff, faculty, and community and were given a blank box to record the circulation period for each patron type. Interestingly, the different terms that librarians used to describe the checkout varied depending on what type of patron they were describing. For example, days and weeks were the most common terms used to describe the duration of undergraduate and community checkouts. The duration of graduate and staff checkouts were often described in days, weeks, and semesters. Faculty checkout duration was frequently explained in terms of a year in addition to days, weeks, and semesters.

In order to make comparisons between libraries, the committee normalized the data using days as the standard. In doing so, it was assumed that a semester checkout was 120 days. The survey responses using the word "term" were eliminated from the analysis since this word is used in a variety of ways at different institutions (only 3 instances per patron type were eliminated). After normalizing the data, the committee was able to analyze the various circulation periods and make comparisons between different patron types.

The average checkout period for undergraduates was 35 days, though the median and mode were 28 days (four weeks). The average graduate checkout period was 117 days with a median and mode of 120 days or one semester. The faculty average was 186 days, though this group has the largest standard deviation and difference between median (126 days) and mode (120 days) (See Table 1: Number of Days Different Groups Can Checkout Materials in Academic Libraries). 
Table 1: Number of Days Different Groups Can Checkout Materials in Academic Libraries

\begin{tabular}{|l|c|c|c|c|c|c|c|}
\hline & Minimum & Maximum & Average & Median & Mode & $\begin{array}{c}\text { Standard } \\
\text { Deviation }\end{array}$ & $\begin{array}{c}\text { Number of } \\
\text { libraries }\end{array}$ \\
\hline Undergraduate & 14 & 142 & 35 & 28 & 28 & 25 & 74 \\
\hline Graduate & 14 & 365 & 117 & 120 & 120 & 90 & 71 \\
\hline Staff & 14 & 365 & 118 & 120 & 120 & 90 & 71 \\
\hline Faculty & 14 & None & 186 & 126 & 120 & 108 & 71 \\
\hline Community & 0 & 180 & 27 & 28 & 28 & 20 & 68 \\
\hline
\end{tabular}

Figure 1 (Undergraduate and Community Checkout Periods in Academic Libraries) provides a better picture of the distribution of checkouts for undergraduate and community patrons. As can be seen, the majority of undergraduate and community checkouts ranged between 14 and 35 days (inclusive) with 28 days (four weeks) being the most common. Most graduate, staff, and faculty checkout periods were 120 days, though there were several libraries that gave these groups 180 days. There were also a significant number of institutions that offered a full year checkout to faculty, and one even offered checkouts with no due date.

Figure 1: Undergraduate and Community Checkout Periods in Academic Libraries

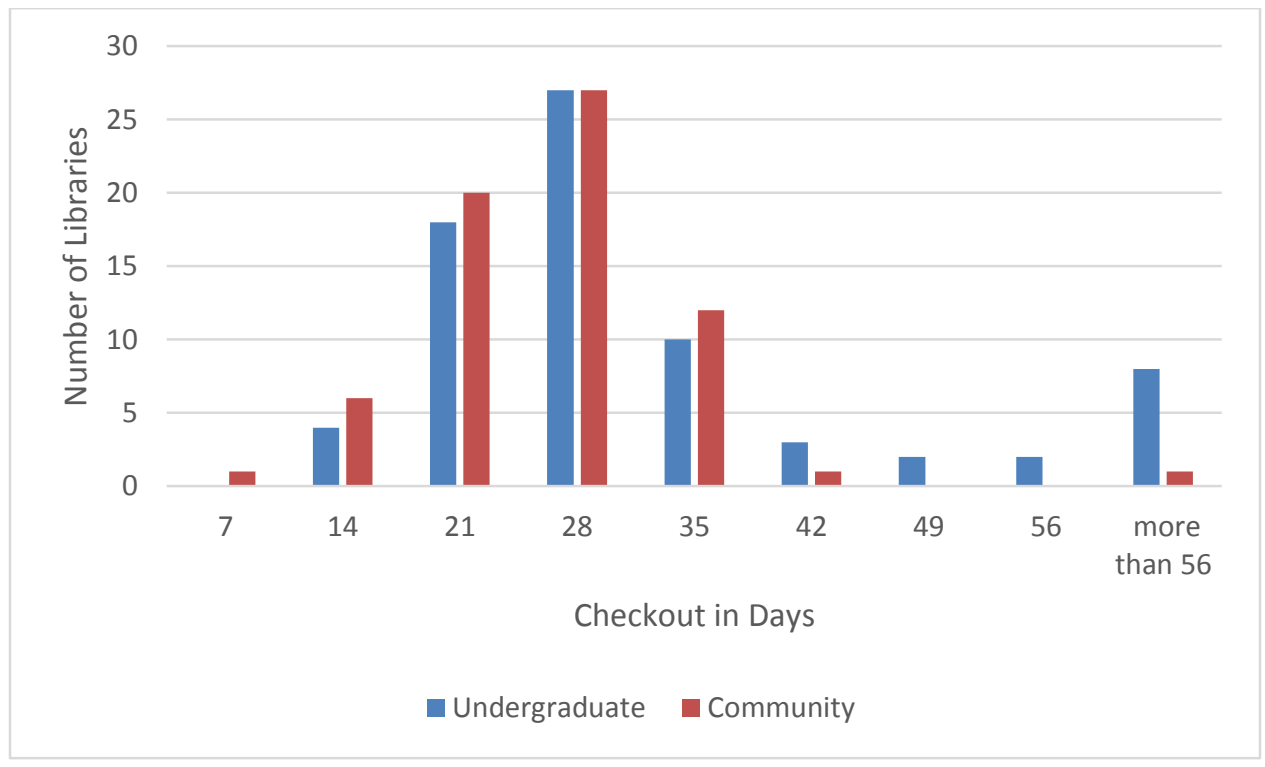


For graduate and faculty patrons, the checkout periods were most often 120 days (one semester), 182 days (half of the year), or 365 days (a full year). The majority of libraries gave graduates and faculty a semester-long checkout (as is evidenced by the mode of 120), though a significant number of libraries gave faculty members a year-long checkout.

Note that the majority of checkout periods fell at eight specific checkout durations as seen in Table 2: Most Common Checkout Periods at Responding Libraries. As was mentioned above, the number 120 was used to represent one semester in the normalized data. The number representing 240 was used to represent an academic calendar year.

Table 2: Most Common Checkout Periods at Responding Libraries

\begin{tabular}{|c|c|c|c|c|c|}
\hline & \multicolumn{5}{|c|}{ Number of Libraries } \\
\hline \# of Days & Undergraduate & Graduate & Staff & Faculty & Community \\
\hline $\mathbf{1 4}$ & 4 & 1 & 2 & 1 & 6 \\
\hline $\mathbf{2 1}$ & 27 & 3 & 11 & 1 & 27 \\
\hline $\mathbf{2 8}$ & 19 & 3 & 4 & 1 & 21 \\
\hline $\mathbf{3 0}$ & 10 & 2 & 1 & 1 & 12 \\
\hline $\mathbf{1 2 0}$ & 4 & 21 & 20 & 21 & 0 \\
\hline $\mathbf{1 8 0}$ & 0 & 9 & 7 & 10 & 1 \\
\hline $\mathbf{2 4 0}$ & 0 & 4 & 3 & 5 & 0 \\
\hline $\mathbf{3 6 5}$ & 0 & 2 & 5 & 16 & 0 \\
\hline $\begin{array}{c}\text { total } \\
\begin{array}{c}\text { \% of } \\
\text { Overall } \\
\text { Total }\end{array}\end{array}$ & 64 & 45 & 53 & 56 & 67 \\
\hline
\end{tabular}

\section{Renewals}

Respondents were asked to report the number of times a patron could renew a book before they had to return it to the library. They were presented with a slider that ranged between 0 and 50 renewals and had a box that they could check if their library offered an unlimited number of renewals. The 
majority of libraries offered 1-11 renewals depending on the patron group, with a few offering 50 or even 99 renewals. In addition, there were a large number of libraries that reported unlimited renewals.

The results are summarized in Table 3: Renewals by Patron Group. The unlimited renewals are not included in the calculation of the average, median, and mode. The larger numbers (50 and 99) were included and did greatly skew the average.

Table 3: Renewals by Patron Group

\begin{tabular}{|l|c|c|c|c|c|c|}
\hline Patron Type & Average & Median & Mode & $\begin{array}{c}\text { Standard } \\
\text { Deviation }\end{array}$ & $\begin{array}{c}\text { Unlimited } \\
\text { Renewals }\end{array}$ & $\begin{array}{c}\text { \# of } \\
\text { libraries }\end{array}$ \\
\hline Undergraduate & 7.7 & 3 & 3 & 18.3 & 14 & 76 \\
\hline Graduate & 7.9 & 3 & 3 & 18.5 & 16 & 74 \\
\hline Staff & 8.0 & 3 & 3 & 18.8 & 18 & 74 \\
\hline Faculty & 8.7 & 3 & 3 & 20.0 & 19 & 71 \\
\hline Community & 7.3 & 2.5 & 2 & 19.0 & 11 & 67 \\
\hline
\end{tabular}

The distribution of renewals gives a better picture of renewal trends in libraries (see Figure 2: Number of Renewals by Library). The majority of libraries offered between one and six renewals. A substantial number of libraries offered 50 or more renewals. 
Figure 2: Number of Renewals by Library

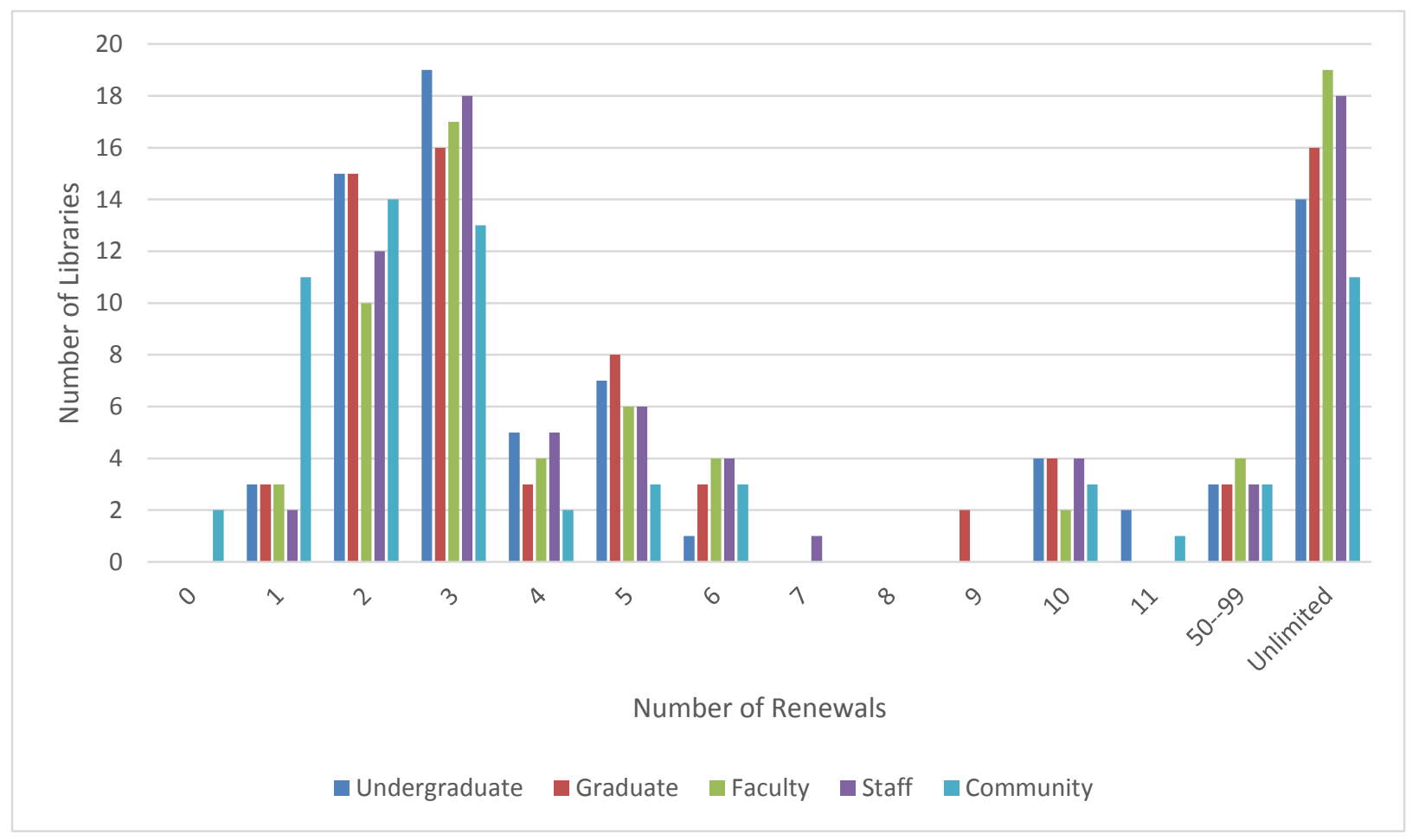

Fines

The survey asked libraries if they charge overdue fines. Of the 77 respondents, the majority, 58 (75\%), do; however, 19 (25\%) do not charge fines, with $13(17 \%)$ of these saying that they used to charge fines but no longer do. However, in examining the comments, seven of the libraries that said they charged fines actually only fined on specialty items or after an item was severely overdue.

Of the 50 libraries that charged daily fines for a book, 38 said that the fine was between $\$ 0.01$ and $\$ 0.25$ per day (76\%). A much smaller number (16\%) said that the fine was $\$ 0.26$ and $\$ 0.50$ per day, with the other $8 \%$ of respondents listing a daily fine higher than $\$ 0.50 /$ day. There were 55 libraries that reported a maximum fine with the majority of libraries (84\%) reporting a maximum fine between $\$ 5$ and $\$ 50$. 
The survey asked those that do charge fines if, in their opinion, library fines encouraged patrons to return their books on time. Of the 58 respondents, 42 (72\%) answered yes, 10 (17\%) answered no, and $6(10 \%)$ responded "I don't know."

The survey asked all respondents their opinion on the effect of charging fines. Respondents were given the opportunity to select all of the options that they felt applied. Given specific options, $74 \%$ of respondents felt that fines help get materials back, $18 \%$ thought that fines discourage use of the library, and $16 \%$ thought that fines do not have any positive effect. Of the "other responses," four mentioned that fines created negative and difficult work for the library employees who collect them. Three responded that fines upset their patrons (See Table 4: Survey Opinion on the Effect of Fines).

Table 4: Survey Opinion on the Effect of Fines $(n=77)$

\begin{tabular}{|l|c|c|}
\hline Answer & Response & \% \\
\hline Help get materials back & 57 & $74 \%$ \\
\hline Discourage use of the library & 18 & $23 \%$ \\
\hline Don't do any good & 12 & $16 \%$ \\
\hline Other & 12 & $16 \%$ \\
\hline
\end{tabular}

The survey asked respondents to make comments about library fines. Of the 32 comments, 11 (34\%) mentioned that fines had a negative effect. Most of these respondents felt that fines were a deterrent for patrons to use the library. It is interesting to note that only $5(15 \%)$ of the comments mentioned that fines helped to get library items returned.

\section{Libraries that Don't Charge Fines}

For those libraries that do not charge fines, the survey asked how they encourage patrons to return their items. Respondents were again given the opportunity to select all responses that applied. Of the 18 libraries that responded, billing for unreturned books and blocking library privileges were by far the most common responses, followed by blocking registration from classes. A distant fourth on the list was blocking graduation (see Table 5: How Does Your Library Encourage Patrons to Return Books?). Of the 
eight libraries who responded "other," four mentioned that transcripts were blocked, while others responded that faculty delivery was suspended.

Table 5: How Does your Library Encourage Patrons to Return Books?

\begin{tabular}{|l|c|c|}
\hline Answer & Response & \% \\
\hline Bill for unreturned books & 17 & $94 \%$ \\
\hline Block library privileges & 18 & $100 \%$ \\
\hline Block university privileges & 6 & $33 \%$ \\
\hline Block registration for class & 13 & $72 \%$ \\
\hline Block graduation & 9 & $50 \%$ \\
\hline Other & 8 & $44 \%$ \\
\hline
\end{tabular}

For the libraries that had stopped charging fines, the survey asked if there had been more, the same amount, or fewer problems with books being returned as a result of the change. A very small majority $(58 \%)$ stated that they had the same number of problems while the rest (42\%) mentioned that they had fewer problems with patrons returning books. None of the libraries reported having more problems with books being returned as a result of eliminating fines.

When asked to discuss any additional changes resulting from eliminating fines, most libraries commented about the goodwill that it generated with patrons or the diminished amount of time that staff members had to dedicate to resolving fine problems. Overall, the libraries that eliminated fines were pleased with the change.

\section{Recalls}

The survey asked what responding libraries do when a patron wants an item that is already checked out. The majority of respondents $(88 \%)$ indicated that their library would recall the item, while $75 \%$ also mentioned that they would also obtain a copy through interlibrary loan (respondents were able to select multiple responses). Of those who selected other, $11(65 \%)$ indicated that they use a consortial service to get access to the item and $3(17 \%)$ indicated they place a hold on their library's copy of the item. (See Figure 3: What Libraries Do When a Patron Wants an Item that is Checked Out). 
Figure 3: What Libraries Do When a Patron Wants an Item that is Checked Out

\begin{tabular}{|c|c|c|c|}
\hline Answer & Response & $\%$ \\
\hline $\begin{array}{c}\text { Recall the item. } \\
\text { Interlibrary loan } \\
\text { a copy of the } \\
\text { item. }\end{array}$ & 66 & $88 \%$ \\
$\begin{array}{c}\text { Purchase an } \\
\text { additional copy } \\
\text { of the item. } \\
\begin{array}{c}\text { The patron has to } \\
\text { wait until the } \\
\text { item is returned. } \\
\text { Other }\end{array}\end{array}$ & 17 & $75 \%$ \\
\hline
\end{tabular}

The survey asked respondents why their library would recall an item. Most of the responding libraries (95\%) stated that they would recall for a professor placing items on reserve and $94 \%$ said they would recall for another patron that needed the item. When asked if they were happy with the current recall system, the majority of libraries (66\%) responded in the affirmative.

Despite the statement that they are generally happy with recalls, there were multiple comments from respondents about the problems that recalls cause. These comments were typically related to problems with the recall system, patrons not wanting to return items, and patron confusion about the system.

\section{Discussion}

Based on the results of the survey, traditional policies are defined as more restrictive in nature and focused on short checkout periods and timely returns. The majority of policies at major academic libraries in the United States (as evidenced by this survey) are more restrictive and traditional. The more non-traditional set of policies, while in the minority, are less restrictive, with more generous circulation periods and low or no fines. It seems that these policies better reflect patrons' needs and desires. The 
survey results show a specific distinction between traditional and non-traditional policies shown in Table 6: Traditional and Non-traditional Policies in Major Academic Libraries.

Table 6: Traditional and Non-traditional Policies in Major Academic Libraries

\begin{tabular}{|l|c|c|}
\hline $\begin{array}{l}\text { Undergraduate } \\
\text { Circulation Period }\end{array}$ & Traditional/Majority & $\begin{array}{c}\text { Non-traditional/Minority } \\
\text { More than } 30 \text { days, with } 120 \text { days } \\
\text { being the most common }\end{array}$ \\
\hline $\begin{array}{l}\text { Graduate/Staff } \\
\text { Circulation Period }\end{array}$ & 120 days & 180 days or more \\
\hline $\begin{array}{l}\text { Faculty Circulation } \\
\text { Period }\end{array}$ & 120 days & 365 days or more \\
\hline Renewals & $1-3$ & More than 11 \\
\hline Fines & $\begin{array}{c}\$ .01-\$ .25 / \text { day with between } \$ 10-\$ 50 \\
\text { maximum }\end{array}$ & No regular overdue fines \\
\hline Recalls & $\begin{array}{l}\text { The library recalls items from the } \\
\text { patron who has them checked out }\end{array}$ & $\begin{array}{c}\text { The library obtains a copy through } \\
\text { interlibrary loan }\end{array}$ \\
\hline
\end{tabular}

Past policies were based on circulation as the most prominent of library services. They focused on protecting materials by limiting their use and punishing patrons for misuse. In our current era of continuously declining circulation and the prominence of electronic resources, restrictive circulation policies based on past circulation trends are difficult to justify.

Indeed, the statement by Hartse \& Lee (1992) seems very applicable in our current era: "Unfortunately, circulation policies are often maintained purely by inertia. They are adopted at one stage in a library's development as a response to certain conditions, and then preserved through periods of change, both superficial and fundamental, in the way the library is used. They are maintained even though no one can quite remember why such rules were established."

The allowance for longer checkout periods, more renewals, the elimination of fines, and exploration of an alternative to recalls are viable and very compelling alternatives. Though lesstraditional policies are still very much in the minority, the libraries that have adopted these policies have been satisfied with the changes. 


\section{Correlation}

After the initial analysis was completed, additional analysis was done in order to determine if there was a correlation between the various forms of traditional and non-traditional policies. The committee wanted to know how many libraries had non-traditional policies and if it was likely for a library with a non-traditional policy to have other non-traditional policies.

Surprisingly, 74\% (56/76) of libraries had at least one non-traditional policy for one of their patron groups. Of these, the most common was to have a non-traditional circulation policy for at least one patron group (53\%). It should be noted that, even though the majority of libraries had at least one non-traditional circulation policy, only $26 \%$ of libraries had non-traditional circulation policies for more than one patron group. Only one of the 76 libraries (1\%) offered a non-traditional circulation period for four patron groups.

For renewals, $34 \%$ of libraries had at least one non-traditional renewal policy. It was more common for these libraries to offer non-traditional renewals across patron groups, with a full $20 \%$ of all libraries offering non-traditional renewal polices for all five patron groups (students, grad students, faculty, staff, and community). It should be noted that fine policy by patron group was not collected as part of the survey.

As far as correlation between non-traditional policies, there was none. For libraries that had traditional policies in one area, it was much more likely for them to have traditional policies in other areas. However, if a library had a non-traditional policy it was not predictive of a library having other non-traditional policies. In addition, even though $74 \%$ of libraries had at least one non-traditional policy for at least one patron group, most libraries still had traditional policies for the majority of patron groups. 


\section{Application}

After evaluating the results from this study and other internal studies, the Harold B. Lee library decided to adopt some non-traditional circulation policies in order to better serve the needs of its patrons. The undergraduate circulation period was increased from three weeks to six weeks. With the already existing three unseen renewals, this allows our patrons the ability to keep books for an entire semester without returning them. In addition, the library chose to eliminate regular overdue fines for book checkouts and use the billing process to incentivize book returns.

To improve our recall system, the library chose to develop a technological system that will improve our ability to determine how quickly the requesting patron needs an item that is already checked out and help determine how difficult it will be for patrons who have an item checked out to return the item. When a patron places a hold (now called a request), the system no longer creates a recall by default. It first determines if other editions of the same work could fill the request. If all editions of an item are currently checked out, then the system places a blanket hold on all editions, allowing the first item returned to fill the hold. The system also emails the patrons who currently have one of the items checked out and asks them to return the item if they no longer need it. If the item is not returned within four days, then another email is automatically sent to the requesting patron informing them that they can request the item through interlibrary loan. Staff members can still recall items manually if needed

The six week checkout and elimination of regular overdue fines was implemented in January 2014. The students are very happy with the increase in circulation period and assessments have shown that the change was successful. More discussion on the decision processes for this change can be found in Wilson (2014).

\section{Conclusion}

As circulation continues to decrease in academic libraries (Wilson 2013), updating circulation policies to provide a stronger patron focus can build good will and encourage patrons to use library 
materials. The justification for the old model of shorter undergraduate circulation periods and few renewals is not based on the needs of those who are currently using the items. The literature and experience with eliminating fines show that alternative methods for incentivizing book returns are effective, increase patron satisfaction, and reduce staff processing time. The non-traditional methods tend to be more liberal and to provide materials to patrons with fewer constraints. The libraries who use these methods report higher patron satisfaction and no additional problems with the return and preservation of their materials. It is time for libraries to more seriously examine their circulation polices and determine if they can better meet the needs of their patrons through more generous policies.

Note: Portions of this research were presented as Breaking with Tradition: Fines, Recalls, Circulation and Renewals at Academic Libraries at ACRL, March 2015, Portland, Oregon and Utah Library Association, May 2015, Saint George, Utah.

\section{References}

Brophy, P. \& Moorhouse, P. (1984). The Operation of a Variable Loan Policy within an Automated Library System. Program: Electronic Library \& Information Systems, 18(2), 166-169.

Burgin, R. \& Hansel, P. (1984). Library Overdues: Analysis, Strategies, and Solutions to The Problem, eds. Burgin, R., Hansel, P. New York, NY: Haworth Press.

Dethloff, N. (2012). Replacing Recalls with Interlibrary Loan: The University of Houston's QuickLoan Service. Journal of Access Services, 9(1), 18-27.

Fried, A. K. \& Hurlebaus. A. J. (1981). A Reevaluation of Circulation Policies: Overdue Process and Loan Period. Special Libraries, 72(3), 284-289.

Goehlert, R. (1979). The Effect of Loan Policies on Circulation Recalls. Journal of Academic Librarianship, 5(2), 79. 
Hartse, M. A. \& Lee, D. R. (1992). Changing circulation policies at an ARL library. The impact of peer institution survey data on the process, Collection Management, 17(1), 133-148.

Mosley, P. A. (2004). Moving Away From Overdue Fines: One Academic Library's New Direction. Journal of Access Services, 2(1), 11-21.

Reed, K., Blackburn, J. \& Sifton, D. (2014). Putting a Sacred Cow Out to Pasture: Assessing the Removal of Fines and Reduction of Barriers at a Small Academic Library, The Journal of Academic Librarianship, 40(3), 275-280.

Rupp, E., Sweetman, K. \& Perry, D. (2010). Updating Circulation Policy for the 21 st Century. Journal of Access Services, 7(3), 159-175.

Shontz, D. (1999). Effect of Fines on Length of Checkout and Overdues in a Medical Library. Bulletin of the Medical Library Association, 87(1), 82-84.

Sifton, D. J. (2009). The Last Taboo: Abolishing library fines. Partnership: The Canadian Journal of Library and Information Practice and Research, 4(1), 1-4.

Sung, J. S. \& and Tolppanen, B. P. (2013). Do Library Fines Work?: Analysis of the Effectiveness of Fines on Patron's Return Behavior at Two Mid-sized Academic Libraries. The Journal of Academic Librarianship, 39(6), 506-511.

Wilson, D. (2013). Re-envisioning Access Services Departments in ARL Libraries. Journal of Access Services, 10(3), 153-171

Wilson, D. (2014). Why Can't they Keep the Book Longer and Do they Really Need to Charge Fines? Assessing Circulation Policies at the Harold B. Lee Library: A Case Study. Journal of Access Services, 11(3), 135-149. 
Zweibel, S \& Lane Z. (2012). Probing the Effects of Policy Changes by Evaluating Circulation Activity Data at Columbia University Libraries. The Serials Librarian, 63(1), 17-27. 